\title{
The involvement of utilities in the development of broadband infrastructure: a comparison of EU case studies.
}

\begin{abstract}
Energy companies and other utility providers have been often involved in the provision of telecommunications services. Nevertheless, their contribution to broadband development has varied significantly over time. In the late 1990s, both local and national utilities in the European Union (EU) engaged in the provision of broadband networks, but only few of them managed to establish themselves as major broadband providers. More recently, new projects involving national utilities have been announced in several EU countries, opening new scenarios for utilities' contribution to Next Generation Access (NGA) development. This paper identifies and explores the factors affecting the entry and the success of utilities in the EU broadband market, through the comparison of four case studies from four EU countries (Germany, Italy, Sweden and the UK). The evolution of utility involvement in the EU broadband markets is assessed against the interaction of market, technology and policy factors, focusing on the impact of policy and regulatory measures. As a result, this paper provides fruitful insights into the relevance and effectiveness of public interventions in broadband markets. Across the four case studies, public support and public ownership emerged as the main drivers for the involvement of utilities in EU broadband markets, with regulatory measures and economies of scope exerting a limited and decreasing influence. However, the contribution of utilities has varied significantly across the cases studied, reflecting the different approaches taken at national and local level to support broadband development, in spite of the common regulatory framework.
\end{abstract}

\section{Keywords}

Utility providers; broadband investment; broadband policy; open-access networks. 


\section{Introduction}

Superfast broadband ${ }^{1}$ is increasingly perceived as an essential service to foster economic growth and social development (Broadband Commission, 2015). The European Union (EU) committed to achieve universal access of $30 \mathrm{Mbps}$ by 2020 (EC, 2010b) and to $100 \mathrm{Mbps}$ by 2025 (EC, 2016c). However, a large number of European citizens are still unable to access next-generation access (NGA) networks ${ }^{2}$, especially in rural areas (EC, 2016a). Ad hoc policies have been, therefore, adopted to address those factors hindering the diffusion of superfast broadband (BEREC, 2016).

Since the late 1990s, ex-ante regulation has promoted competition and investment by granting access to network bottlenecks (Picot \& Wernick, 2007). Furthermore, local and central governments have been actively supporting the supply of NGA networks where the market has failed to provide superfast broadband access (Cave \& Martin, 2010). Alongside public authorities and broadband companies, alternative infrastructure providers have also contributed to NGA development (Gerli et al., 2017).

In particular, utilities - such as electricity providers or water companies (see section 2 for a more detailed definition) - have often been involved in the provision of broadband services (Mölleryd, 2015; Troulos \& Maglaris, 2011). They either acted as provider of passive infrastructures or retailed broadband in bundle with other utility services (Van der Wee et al., 2011). The actual contribution of utilities to broadband development has varied across the EU. In some countries, such as Sweden, utilities are a key driver of NGA supply, but in other countries, such as the UK, their role has been limited (Ragoobar et al., 2011). Nevertheless, the synergies between utilities and telecommunications providers have been frequently emphasised by scholars (Gillett et al., 2006), practitioners (Analysis Mason, 2008) and policymakers (Department for Business Innovation and Skills, 2010).

Over the past few years, a number of new projects involving utilities in the European NGA market have been announced. The Italian incumbent in the electricity distribution market established a new company to roll out fibre-to-the-home (FTTH) in more than 200 cities (EOF, 2016). Similarly, Vodafone and the Irish energy incumbent have partnered with one another

\footnotetext{
${ }^{1}$ Superfast broadband differs from basic broadband in terms of bandwidth and download speed. Consistent with EC 2010b), this paper defines superfast broadband as providing a minimum download speed of $30 \mathrm{Mbps}$. ${ }^{2}$ According to EC 2010a), NGA networks are fibre-based access networks delivering high-capacity connectivity. They comprise a wide range of technologies, such as a fibre-to-the-cabinet (FTTC), fibre-to-the-building/home (FTTB/H), DOCSIS 3.0.
} 
since 2015 to provide 500,000 premises with FTTH (TeleGeography, 2015). Furthermore, Orange has signed an agreement with SNCF, the French railway operator, to use and resell the capacity of the latter's fibre network (TeleGeography, 2016b).

To the best of our knowledge, these recent trends have not been thoroughly examined by scholars; previous studies mainly assessed the effects of regulations on broadband investment on a general level or focused on the interplay between the incumbent and the new entrants (Briglauer et al., 2014; Cambini \& Jiang, 2009). This paper aims to fill this research gap, through a longitudinal case study analysis exploring the role of utilities in EU broadband markets over the past 20 years. The framework developed, based on the market-policytechnology interactions approach of Van der Wee et al. (2014), is applied to analyse the factors underlying the involvement of utilities in four European broadband markets - Germany, Italy, Sweden and the United Kingdom.

Accordingly, our analysis addresses three research aims. First, it examines the strategies of utilities investing in broadband markets to identify the drivers of their entry. Secondly, it assesses how different policies and regulatory measures have affected the role of utilities over time. Third, it outlines and discusses the evolution of utility involvement in the EU broadband market .

The case study analysis aims to explore the trends observed in the market, in relation to the extant literature on broadband investment. Being an exploratory study, a theoretical contribution is not the primary goal of this paper. Our case studies provide in-depth insights that can help develop and enhance both the conceptualisation and the policymaking of broadband investments.

The cross-country comparison reveals that the relevance of scope economies as a driver of utilities in the broadband market has decreased over time, while public support has become the most influential factor. These findings partially conflict with earlier research emphasising the scope economies in network rollout as a major advantage for utilities investing in broadband markets (Angelou \& Economides, 2013; Tadayoni \& Sigurðsson, 2007).

We also observe that the intensity of public interventions in support of national and local utilities has varied considerably across the EU, despite the common regulatory framework. Our research sheds light on the interaction between local and central institutions in the development of broadband markets, an aspect that has been generally overlooked in the extant literature about public policy in the ICT ecosystem (Montolio \& Trillas, 2013). 
In the remainder of this paper, the market structure and the regulatory framework of utilities and telecommunications markets are described in Section 2 and Section 3 respectively. Section 4 reviews the extant literature regarding the contribution of utilities to broadband development, while the methodology and the framework underlying our analysis are explained in Section 5. The case studies are presented in Section 6 and discussed in Section 7. Finally, Section 8 outlines our concluding remarks and policy recommendations.

\section{Market structure and public policy in European utilities markets}

Prior to start our analysis, it is worth outlining the context and the scope of our research, clarifying the concept of utility adopted in this paper. The term 'utilities' generally covers those organisations providing essential services such as energy (gas, electricity and heating), water and sewerage, telecommunications, transportation and waste collection (McNabb, 2016).

Being perceived as public local goods (Pinch, 1985) and natural monopolies ${ }^{3}$ (Bös, 2015), these services have historically been provided by public enterprises (Stephen, 1997): municipal utilities have existed since the late Nineteenth century (Wollmann, 2013). After World War II, though, these industries were generally nationalised, resulting into the creation of nation-wide vertically-integrated public monopolies (Pollitt \& Steer, 2012).

Market liberalisation, which started in the early 1980s, has radically transformed the structure of utility markets and the role of the public sector in these industries. National monopolies were, at least partially, privatised and markets were opened up to competition (Heddenhausen, 2007). Sectoral authorities have been established to regulate the open market and safeguard public interest in the provision of these essential services - see, for example, Coen \& Doyle (2000) and EY (2013) for further details.

The markets for electricity and gas services have undergone significant changes over the past 20 years. In the late 1990s, the EU mandated the unbundling of energy incumbents to enable competition in the different stages of the value chain (Torriti, 2010). As a result, the generation and the trading of energy are now competitive markets, while transmission and distribution networks are still either national or local monopolies (Asquer, 2011).

\footnotetext{
${ }^{3}$ Utilities such as electricity and water can be classified as public local goods, being "freely available at equal costs within particular local government units or administrative areas" (Pinch, 1985, p. 10). They are also considered natural monopolies, being characterised by high fixed costs and low variable costs (Bös, 2015).
} 
The provision of water and sewerage services has also been subject to regulatory interventions, but its integration at the European level is still limited (Ménard, 2017). Significant variations persist across EU Member States in the governance of water services. Historically controlled by publicly owned local monopolists, these services are currently either provided by municipal utilities or outsourced to private companies (Delimatsis, 2015).

Despite a constant trend towards harmonisation and integration at the EU level, national utility markets still differ widely in terms of their structure and network governance (EY, 2013). Competition has developed in the retailing of utility services, while the infrastructures are still either local or national monopolies. Networks providers can be either private, public or even mixed companies, as the implementation of privatisation varies significantly across Member States (Heddenhausen, 2007) similarly to what happened in the telecommunications market (OECD, 2013).

\section{Market structure and public policy in the European telecommunications market}

Like other network industries, the structure of the telecommunications market has radically changed over the past 30 years. Ex-ante regulation has enabled service-based competition to develop in retail markets, but the access networks are still a monopoly except for those areas where alternative infrastructures (cable or fibre networks) have been deployed (BEREC, 2016). Based on the work of Falch \& Henten (2015), three phases can be identified in the policymaking of telecommunications markets at the EU level (Table 1)

The first phase focused on the opening up of telecommunications markets to competition. The transformation from a vertically integrated monopoly to a competitive market relied on the enforcement of pro-competitive regulation, as defined by Directive 2002/21/EC. Asymmetric obligations were imposed to incumbents with significant market power (SMP) to enable the new entrants to access network bottlenecks such as the local loop ${ }^{4}$.

The regulatory framework was successively updated to support the development of NGA networks. Recommendation 2010/572/EU introduced symmetric regulation, which extends access obligations to any operator in control of NGA bottlenecks (such as terminating fibre), regardless of their market power (EC, 2013). On the other hand, Directive 2013/466/EU

\footnotetext{
${ }^{4}$ That is the last mile between the phone exchange and the end-users' premises.
} 
proposed lighter regulation on SMP operators adopting an equivalence-of-input ${ }^{5}$ approach, with this being considered the most effective model to enforce non-discrimination obligations (Directive 2013/466/EU).

Table 1: Telecommunications policy in Europe

\begin{tabular}{|c|c|c|c|}
\hline $\begin{array}{l}\text { Legal } \\
\text { sources }\end{array}$ & Aim & Policy measures & References \\
\hline \multicolumn{2}{|c|}{ Before liberalisation } & Full public ownership & Bauer (2010) \\
\hline $2002 / 21 / \mathrm{EC}$ & Competition & $\begin{array}{l}\text { SMP regulation (access/non- } \\
\text { discrimination) }\end{array}$ & $\begin{array}{l}\text { Cambini et al. (2009) } \\
\text { Krämer and Schnurr } \\
\text { (2014) }\end{array}$ \\
\hline 2010/572/EU & \multirow{2}{*}{$\begin{array}{l}\text { NGA } \\
\text { promotion }\end{array}$} & Symmetric regulation & \multirow{2}{*}{$\begin{array}{l}\text { Briglauer, Gugler, et al. } \\
\text { (2013) } \\
\text { Briglauer et al. (2017) }\end{array}$} \\
\hline 2014/61/EU & & $\begin{array}{l}\text { (Reciprocal) Access to existing } \\
\text { networks }\end{array}$ & \\
\hline $\begin{array}{l}2013 / \mathrm{C} \\
25 / 01\end{array}$ & Market failure & State Aid & $\begin{array}{l}\text { Gómez-Barroso and } \\
\text { Feijóo (2012) } \\
\text { Briglauer et al. (2016) }\end{array}$ \\
\hline
\end{tabular}

Source: compiled by the authors, derived on Falch \& Henten (2015).

Considerable emphasis was also placed on the sharing of existing infrastructures and the coordination of civil engineering works. Directive 2014/61/EU encouraged Member States to establish single information points, in order to enhance the transparency about the availability and the location of physical infrastructures and to facilitate the cooperation between telecommunications companies and other infrastructure providers. the principle of reciprocity could also apply, in order to let utility providers reuse existing infrastructures deployed for NGA rollout.

In addition to these regulatory measures, the EU also endorsed supply-side and demandside policies to support NGA diffusion (Briglauer \& Gugler, 2013; Walterova \& Tveit, 2012). In 2010, the Digital Agenda for Europe (DAE) set a number of targets that Member States are committed to achieve by 2020, including universal access to broadband and superfast broadband (EC, 2010b). These targets were updated in 2016 towards achieving a "European Gigabit Society" by 2025 (EC, 2016c).

\footnotetext{
${ }^{5}$ This implies that access services are provided to internal and third-party users through the same process, on the same terms and conditions. The application of this principle led, for example, to the functional separation of Openreach from British Telecom (Whalley \& Curwen, 2008).
} 
In order to achieve the coverage targets set by the DAE, central and local governments have undertaken a number of initiatives to bridge the access divide across the EU (Feldmann et al., 2014). These have been justified by the market failure in the provision of broadband, (GómezBarroso \& Pérez-Martínez, 2005) that impedes universal access to NGA networks (Nucciarelli et al., 2014). On the other hand, public interventions in broadband markets have been questioned, as they could crowd out private investment and distort competition (Briglauer et al., 2016; Sadowski et al., 2009).

Guidelines for State aid in broadband markets were adopted by the European Commission in 2009 (WIK, 2011) and reviewed in 2013 (EC, 2013). In order to ensure that public interventions are compatible with article 107 TFEU6, public funds can only be invested in those areas where either none or just one NGA network is expected to exist within three years. Subsidised operators are subject to ex-ante regulation and obliged to provide their competitors with wholesale access to the publicly funded networks.

In 2016 reform of the European Electronic Communications Code was proposed (EC, 2016b), to complement existing regulatory measures and address the ongoing trends in telecommunications such as the transition to all-IP fibre-based networks and fixed-mobile convergence. In particular, the new framework aims to further encourage investment and competition by limiting the scope of ex-ante regulation to those areas where commercial arrangements do not deliver competitive outcomes and co-investment agreements are in place.

\section{Literature review: the role of utilities in broadband development}

The contribution of utilities to broadband development has been widely explored and discussed by researchers and practitioners alike (Angelou et al., 2013; Gillett et al., 2006; Matson \& Mitchell, 2006). The cooperation between utilities and telecommunications providers was identified as a facilitator of broadband deployment (Troulos et al., 2011), but utilities have also emerged as alternative network providers competing with the incumbents in the delivery of superfast broadband (Tadayoni et al., 2007).

The partnership between telecommunications operators and utility providers is expected to minimise the costs and the timing of broadband rollout, by sharing passive infrastructures ${ }^{7}$ or

\footnotetext{
${ }^{6}$ The article 107 TFUE lists the conditions that makes State aid compatible with the internal market.

${ }^{7}$ Broadband networks are composed of three layers: the passive infrastructure (duct, trenches and poles), the active equipment (routers, DSLAM, etc.) and connectivity services (EC, 2014b). The largest proportion of
} 
coordinating civil engineering works (Angelou et al., 2013). Analysis Mason (2008) estimated that the reuse of existing infrastructures could reduce the costs of FTTH deployment in the UK by $25 \%$. The model developed by Tahon et al. (2014) confirmed that the cooperation between broadband and utility providers generates considerable cost savings in the rollout, but these could be offset by greater transaction costs due to asymmetric information.

Furthermore, utilities have a long track record as providers of connectivity services. Many national operators, such as ENEL in Italy and SNCF in France, had developed long-distance fibre networks for internal use, which were employed for the provision of retail services after the liberalisation of telecommunications markets (Falch \& Lorz, 1999). In the early 2000s, local utilities in Europe and the US also entered the broadband market by installing city-wide fibre or wireless networks (Gillett et al., 2004).

Economies of scope in infrastructure deployment and network management were identified as the main drivers of the entry of utilities in broadband markets (Angelou et al., 2013; Tadayoni et al., 2007). Furthermore, local utilities could also leverage their brand and their customer base to market bundles of services and achieve economies of scope in marketing (Angelou et al., 2013; Troulos et al., 2011). Public ownership also emerged as a key factor for utility involvement in broadband provision (Tadayoni et al., 2007; Troulos et al., 2011).

In the US, the control of utilities gave local authorities the financial capability to support the rollout of municipal networks (Matson et al., 2006), as the investment could be subsidised by the revenues from other utility services (Chaffee \& Shapiro, 2008). This cross-subsidisation strategy was, however, contested as being anticompetitive (Arrison et al., 2007). Both Ford (2007) and Seamans (2012) found a positive relationship between the involvement of utilities and competition in broadband markets.

EU regulation obliges municipal providers to invest on the same terms as private operators, thereby preventing cross-subsidisation (Sadowski et al., 2009). Furthermore, most of the projects led by utilities in the EU have adopted an open-access model (Matson et al., 2006) and offer their passive infrastructures to multiple ISPs on a non-discriminatory basis (Van der Wee et al., 2011). This approach has enhanced competition in the service layer and stimulated broadband diffusion, even though it could result into higher transaction costs (Van der Wee et al., 2015).

rollout costs is due to the civil engineering works needed to deploy the passive infrastructure (Van der Wee et al., 2015). 
In summary, the literature frames cooperation between utilities and telecommunications companies as an enabler of broadband diffusion, by achieving economies of scope in network rollout and reducing the cost of infrastructure deployment. On the other hand, when utilities autonomously invest in fibre networks, an open-access model is considered as more likely to enhance competition and encourage broadband diffusion. However, most of the literature focuses on the early stage of broadband development and does not take into account the most recent trends in the EU market. Thus, this paper explores the factors driving the entry of utilities in NGA market, providing updated and in-depth insights that contribute to addressing this gap in the literature and expanding our understanding of investment decisions in broadband markets.

\section{Methodology}

As summarised in Sections 2 and 3, public policies in European utility markets have been defined by European institutions but transposed to, and implemented at, a national level. A cross-country comparison is likely, therefore, to highlight how the role of utilities in broadband markets has varied across the EU under the same regulatory framework. Consequently, a multiple case study is adopted here to address the following research question: how has public policy affected the strategies of utilities investing in the EU broadband market over the past 20 years?

Figure 1: The Market-Policy-Technology framework

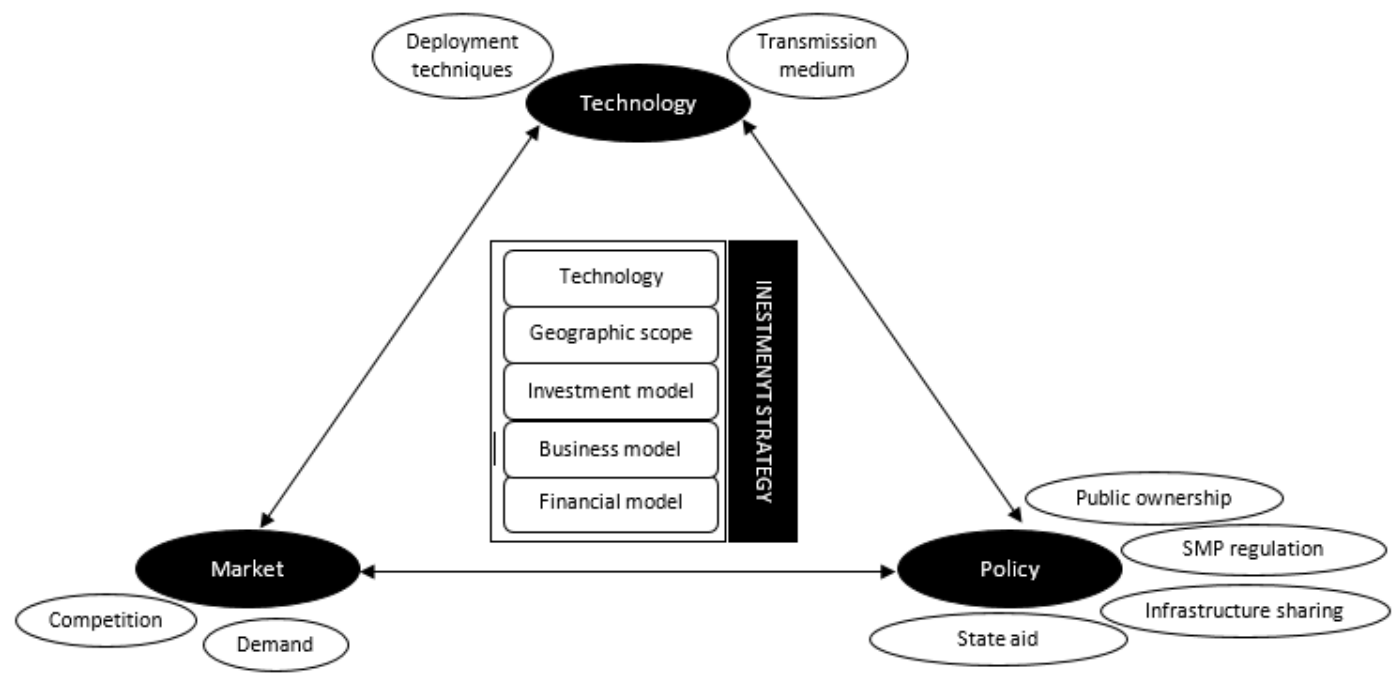

Source: derived from Van der Wee et al. (2014) and Gerli et al. (2017). 
As suggested by Van der Wee et al. (2014) and shown in Figure 1, investment strategies in broadband markets are influenced by the interaction of three dimensions: market, policy and technology. The former includes the demand for broadband services as well as competition in the provision of broadband infrastructure. The policy dimension, in contrast, comprises all the regulatory measures and other forms of public intervention in broadband markets. Finally, the technology dimension is related to innovation in both the passive and active layers of broadband networks, such as new deployment techniques or data transmission standards.

Our analysis focuses on the policy dimension as our primary aim is to understand how regulations and other public interventions have affected the strategies of utilities in broadband markets. As outlined in Figure 1, the policy dimension comprises all the measures discussed in Section 3 and summarised in Table 1. The investment strategy of broadband providers can be described in terms of technology, geographic scope, investment model, business model and financing model (Gerli et al., 2017).

Based on this framework, the involvement of utilities in distinct European countries is explored through a multiple case study (Yin, 2014) - see section 6. A cross-country comparison is expected to highlight both similarities and differences across the case study countries (Eisenhardt, 1989). The focus on selected companies will enable us to dissect the complex relationships that exists between the market, policy and technology variables while the comparison will enhance the generalisability of the findings (Tsang, 2014).

Table 2: Sources of secondary data

\begin{tabular}{|c|c|c|c|c|}
\hline & Germany & Italy & Sweden & UK \\
\hline $\begin{array}{l}\text { Policy } \\
\text { documents }\end{array}$ & $\begin{array}{l}\text { - } \text { Bundesnetzage } \\
\text { ntur (Bnetza) }\end{array}$ & $\begin{array}{l}\text { - AEEGSI } \\
\text { - AGCOM }\end{array}$ & $\begin{array}{l}\text { - OECD } \\
\text { - Swedish Local } \\
\text { Fibre Alliance }\end{array}$ & $\begin{array}{l}\text { - Department for } \\
\text { Business, } \\
\text { Innovation and } \\
\text { Skills } \\
\text { - Competition } \\
\text { Appeal Tribunal } \\
\text { - Ofcom } \\
\end{array}$ \\
\hline $\begin{array}{l}\text { Business } \\
\text { reports }\end{array}$ & $\begin{array}{l}\text { - BREKO } \\
\text { - FTTH Council } \\
\text { - Point Topic } \\
\end{array}$ & $\begin{array}{l}\text { - } \mathrm{CDP} \\
\text { - } \mathrm{OECD}\end{array}$ & $\begin{array}{l}\text { - FTTH Council } \\
\text { - OECD } \\
\text { - Orbion Cons. } \\
\end{array}$ & $\begin{array}{l}\text { OECD } \\
\text { - Oxera } \\
\text { - PRISM } \\
\end{array}$ \\
\hline $\begin{array}{l}\text { Trade } \\
\text { press }\end{array}$ & $\begin{array}{l}\text { - Reuters } \\
\text { - Telegeography }\end{array}$ & $\begin{array}{l}\text { - Corriere delle } \\
\text { Comunicazioni } \\
\text { - Telegeography }\end{array}$ & & $\begin{array}{l}\text { - ISP Review } \\
\text { - The Register } \\
\text { - Thinkbroadband } \\
\end{array}$ \\
\hline
\end{tabular}


Documentary analysis is used as primary method (Yin, 2015). Company reports and press releases were employed to analyse the single case study companies. The evolution of utilities involvement at national level was tracked through the analyses of multiple sources, as detailed in

\section{Table 2.}

The interaction between utility providers and public institutions was further explored through nine semi-structured interviews with managers of the case study companies and representatives of public authorities from the case study countries. These interviewees included one investor relations manager, one regulatory manager, two CTOs, one ICT advisor, one policy advisor, one general director, one top manager and one project manager.

\section{Case studies}

This paper applies the framework explained above to four European broadband markets: Germany, Italy, Sweden and the United Kingdom. These countries are geographically comparable and subject to the same regulatory framework, but differ in terms of broadband development (EC, 2017a) and the structure of utilities markets (Heddenhausen, 2007). As a result, they provide a representative overview of EU utilities market.

For each country, the role of utilities in broadband markets is analysed over time, with a specific focus on a single case study company: M-net (Germany), Metroweb/EOF (Italy), Utsikt (Sweden) and Cityfibre (UK). Some of these companies are not utilities in the strictest sense as they are not directly involved in the provision of utility services, such as energy or gas. However, they are related to utility providers, as the latter acted as either their founders (Metroweb), owners (M-Net, Utsikt, EOF) or partners (Cityfibre).

The national cases have been selected as the most relevant and representative in their country to exemplify the role and the approach of utilities to broadband markets. While the nationwide longitudinal analysis sheds lights on the contribution of utilities to broadband development in each country, the single case study enables an in-depth understanding of their drivers and strategies to emerge. 


\section{I Germany}

German utility markets were long dominated by a number of large private companies (Wollmann, 2013). In parallel, and following the multiple functions undertaken by local governments, municipal multi-utilities (referred to as 'Stadtwerke') were responsible for providing universal access to electricity, water and sewerage services (Greiling, 2013).

Though the EU market liberalization policy first led to a decrease in the responsibilities and geographical spread of the Stadtwerke, recent years indicate a comeback and "remunicipalisation" (Wollmann, 2013). As a result, public and private providers now coexist in German utility markets. As of 2016, 855 energy suppliers operated in Germany: 332 of them distributed both gas and electricity (BnetzA, 2017). The large majority of these providers are municipally-owned Stadtwerke (RAP, 2015).

National utilities have shown an interest in broadband development since the early 2000s. Earlier projects, such as RWE's plan to provide broadband powerline ${ }^{8}$, failed due to technical and regulatory issues (Yuill, 2004). More recently, EWE and Innogy have announced a partnership with Deutsche Telekom (DT) to cooperate in the roll-out of NGA networks (Steitz \& Käckenhoff, 2017). The incumbent will use the utilities' dark fibre to deliver superfast broadband in rural areas, but the networks will be open to other providers as well (Innogy, 2017).

There are also multiple examples of Stadtwerke that operate telecommunications networks. In fact, most of the members of BREKO and BUGLAS, the associations of German alternative broadband operators, are owned by either municipal or regional utilities. These companies have actively contributed to expand the coverage of fibre networks across Germany: for example, 55 (out of 66) utility providers associated with BREKO have been investing either primarily or solely in FTTH (BREKO, 2016).

On the contrary, DT has almost exclusively deployed FTTC (Lemstra \& Melody, 2014), though they recently announced plans for FTTH in a number of specific areas (DTAG, 2017). The incumbent has also planned to employ vectoring to boost the speed of its networks after specific regulation has been introduced to safeguard competition (TeleGeography, 2016a). As of 2016, the incumbent's market share was in line with the EU average (40.7\%) with cable

\footnotetext{
${ }^{8}$ Broadband over Power Line (BPL) is a method for data transmission over the power distribution network. It was retailed to residential customers as an experiment, but was never successful.
} 
operators holding $22 \%$ of the retail market (EC, 2017b). The overall market share of Statdwerke was, however, below 5\% (Point Topic, 2017).

According to Beckert (2017), the success of utilities in the German broadband market has been hampered by legal constraints and the lack of managerial skills at a local level. On the other hand, their involvement in NGA development is likely to increase, as several municipalities are cooperating in special purpose associations (Zweckverband ) to deliver FTTH in rural areas (Wernick \& Bender, 2016).

In this paper, we investigate the specific case of M-Net, a telecom company owned by Stadtwerke München (SWM) and other Stadtwerke in Bavaria. SWM is one of Germany's largest energy suppliers, active in the city of Munich as well as the surrounding area. Apart from electricity, they provide natural gas, district heating, water and public transport as well as telecommunications services since 1996 (Prinz, 2015).

Initially a wholesale customer of Deutsche Telekom, M-net has been deploying its own fibre network since 2009 to address the increasing demand for high-capacity connectivity (FTTH Council Europe, 2012). The company aims to cover $70 \%$ of premises in Munich with FTTB networks by 2021 (SWM, 2016), but it is also deploying G.Fast ${ }^{9}$ (TeleGeography, 2017b)

M-net is vertically integrated as it offers both access and connectivity services. However, M-Net is not regarded as a company with SMP, hence no regulations on opening ducts or wholesale access to competitors apply to it. The company initially deployed its fibre networks in the dense urban city center, but is now expanding to sub-urban and rural areas as well (SWM, 2016).

\subsection{Italy}

The market for utility services in Italy has historically been characterised by the coexistence of national and local monopolists (Argento et al., 2009). As of December 2016, the operators active in the distribution of electricity and gas were 135 and 219, respectively (AEEGSI, 2017). The national energy and gas incumbents were privatised in the late 1990s, yet the Italian

\footnotetext{
${ }^{9} \mathrm{G}$.fast is a transmission standard that combines fibre and copper, achieving a maximum download speed of $300 \mathrm{Mbps}$.
} 
government still holds a majority stake either directly or through Cassa Depositi e Prestiti $(C D P)^{10}$. Municipal utilities have also been partially privatised (Bognetti \& Robotti, 2007).

In the late 1990s, both national and local utilities entered the telecommunications market. The former partnered with international carriers to resell retail services (Brezzi, 2004), but all these ventures were later taken over by telecommunications providers (AGCOM, 2006). In contrast, local utilities did not only act as resellers of retail services but also started to build their own fibre networks as well (Mölleryd, 2015). The actual scope and value of their investments was, however, unclear and most of these projects are thought to have been abandoned (AGCOM, 2010).

The most successful and relevant experience was Metroweb, the network provider founded by AEM, the municipal utility in Milan (FTTH Council Europe, 2015). In 1998, AEM started to roll out a FTTH network while renewing its street lighting infrastructure. Fastweb acted as the commercial partner and the investment was largely funded through the listing of the company on the Milan stock exchange (EPEC, 2012).

After Fastweb's left the joint venture in 2003 (FTTH Council Europe, 2015), Metroweb adopted an open-access model to the provision of dark fibre to major ISPs including the telecommunications incumbent (Amendola \& Pupillo, 2008). Accordingly, Metroweb has never been subject to SMP regulation, but is, instead, subject to symmetric regulation (AGCOM, 2013).

In 2006, AEM sold Metroweb to a private investment fund, but the company was soon under public control once again, as it was acquired by a society controlled by CDP in 2011 (EPEC, 2012). One year later, the company announced a plan to provide $20 \%$ of the Italian population with FTTH (CDP, 2012). Its expansion was in fact limited to Torino, Bologna and Genova, where Metroweb cooperated with local councils (Mölleryd, 2015) and acquired the networks of local utilities (F2i, n.a.).

In spite of its limited footprint, Metroweb has been the major competitor to the incumbent (Telecom Italia) in the broadband infrastructure market, as there are no cable operators in Italy (EC, 2017c). The lack of large-scale facility-based competition resulted in a slower diffusion of NGA networks (Lemstra et al., 2014). However, Telecom Italia has intensified its investment

\footnotetext{
${ }^{10}$ Cassa Depositi e Prestiti is the National Promotional Bank, controlled by the Italian Ministry of Economy and Finance. It is a major shareholder in ENI (incumbent in gas market), Terna (national power grid), Snam (gas transportation) and Italgas (gas distribution). The major shareholder of Enel, the incumbent in energy market, is the Ministry of Economy and Finance.
} 
(CorCom, 2017) since the energy incumbent (ENEL) launched a plan to rollout FTTH networks in 224 cities through its subsidiary Enel Open Fiber (EOF).

EOF initially meant to be deployed the fibre as part of ENEL's project to install smart meters across Italy, but the two plans separated from each other (Campesato, 2016) following the energy regulator's concerns about cross-subsidisation (AEEGSI, 2016). Nevertheless, as of May 2017, EOF had built FTTH networks in nine cities, including those acquired with the takeover of Metroweb in January 2017 (EOF, 2017a, 2017d).

EOF has adopted the same business model as Metroweb. As of May 2017, the company has commercial partnership with four national and three local ISPs, providing retail services over its fibre networks (EOF, 2017b). Furthermore, EOF was awarded $€ 1$.4bn after winning the first auction for NGA deployment in white areas (TeleGeography, 2017a). As a result, EOF will build and manage an open-access public network in a concession lasting 20 years. EOF has also signed an agreement with local authorities and utilities for the reuse of existing infrastructures (EOF, 2017c, 2018).

\subsection{Sweden}

The utility industry in Sweden is largely controlled by public enterprises. The national power grid is owned by the Swedish government, which also controls one of the three regional grids (Orbion Consulting, 2015). Local utilities are predominantly provided by municipallyowned limited companies, regulated by private law (Argento et al., 2009). Swedish municipalities are given wide planning powers and are relatively autonomous but need to abide by the 'cost price' and the 'equality' principles (Mölleryd, 2015). Accordingly, municipalities cannot make a profit from their business activities and must ensure the same treatment is given to any citizen (Argento et al., 2009).

Utilities have been significantly involved in Swedish telecommunications market since the mid-1990s. Regional and national power grids have invested in backbone networks (Orbion Consulting, 2015). Local utilities have, instead, focused on the deployment of access networks. As a result, 200 (out of 290) municipalities are covered by local networks providing $58 \%$ of fibre connections in Sweden (Mölleryd, 2015). Both municipal and regional utilities have benefitted from public subsidies, within the context of initiatives from the government to support ICT and broadband diffusion in the early 2000s (Lemstra et al., 2014). 
The increasing cooperation between local authorities has led to the integration of their networks, though the creation of a single platform for wholesale customers to acquire the related access services (Swedish Local Fibre Alliance, 2014). In fact, only 7\% of municipal broadband providers are vertically integrated (Swedish Local Fibre Alliance, 2014). The focus of Swedish institutions on the provision of dark fibre has favoured the adoption of open-access business models (FTTH Council Europe, 2013) that are considered as an enabler of competition in the retail market (Mölleryd, 2015).

The Swedish retail broadband market is considered as highly competitive (Lemstra et al., 2014): as of July 2016, the incumbent's market share was $37.1 \%$ (EC, 2017d). Unlike other EU incumbents, Teliasonera has been investing in FTTH through its subsidiary Skanova (FTTH Council Europe, 2015). As a result, FTTH is the predominant technology in Sweden (50\% of the market), followed by DSL (31\%) and cable (18\%).

A specific example of utility broadband deployment is Utsikt Broadband, which was founded in 1995 and now control a regional fibre network connecting three cities in Sweden: Mjölby, Linköping and Katrineholm. The fibre network connects over 50,000 homes and businesses and is owned by two energy companies, who in turn are owned by the respective municipalities (Ahl, 2017).

The network is operated in an open access manner - Utsikt offers both dark fibre access and wholesale connectivity and does not contract end-customers themselves. It is important to mention, however, that Utsikt started out as a vertically integrated operator, providing telephony and internet services as well. Facing competition from larger service providers, it decided to change its business model to open-access. The company is now achieving a larger customer base through deals with more than 25 service providers (Ahl, 2017).

Utsikt's infrastructure covers both urban and rural areas. The company was awarded public funds from the Swedish government and the European Agricultural Fund for Rural Development to connect 16 rural communities (Teliasonera, 2011). It is important to note, however, that overall, in 2014, public subsidies covered only $10 \%$ of local providers' investments, which are predominantly funded by revenues and loans (Swedish Local Fibre Alliance, 2014). 


\subsection{United Kingdom}

Initially provided by either regional or national public authorities (Pollitt et al., 2012), utility services in the UK are currently controlled by private providers. Electricity is distributed by 14 regional networks owned by six private providers (Ofgem, 2017a), while gas distribution is managed by eight regional companies owned by four private providers (Ofgem, 2017b). Water and sewer services are provided by 26 private companies across England and Wales, while public monopolies are still operating in Scotland and Northern Ireland (Ofwat, 2017).

Broadband projects involving utility companies flourished in the early 2000s. Sewer and water companies were either offering open access to their infrastructures (BBC News, 2004) or partnering with ISPs (Wakefield, 2002), while energy utilities retailed ADSL or BPL in Scotland (Jackson, 2003). In 2008, H2O, a telecommunications company, announced a plan to deploy FTTH networks through the sewerage networks in Dundee and Bournemouth (Williams, 2008). However, cooperation between utilities and telecommunication operators was the exception rather than the rule (Department for Business Innovation and Skills, 2010) and most of these initiatives were later taken over by telecommunications companies (Ray, 2008) or abandoned due to contractual and legal issues (Hunt, 2010).

H2O was bought by its managers in 2011 and rebranded as Cityfibre. The new company inherited the infrastructure built in partnership with utility providers and launched an ambitious expansion plan across the UK. Although Cityfibre no longer engages with utility providers, its growth strategy mainly relies on leveraging existing infrastructures previously developed by local network providers (Gerli et al., 2017).

Since 2011, Cityfibre has either acquired or built pure fibre networks across the UK, focusing on second-tier cities. It is emerging as a major competitor to BT in the provision of pure fibre metro networks ${ }^{11}$ (PRISM, 2014), by offering passive and active services on an openaccess basis. As of December 2016, it ran 42 metro networks, with 4,235 sites already connected and 400,000 sites addressable in June 2017 (Cityfibre, 2017b).

Cityfibre also owns FTTH networks in Bournemouth and York ${ }^{12}$, covering 21,000 and 14,000 premises, respectively (Cityfibre, 2017a). In July 2017, the company announced a new plan to extend its fibre rollout to five to 10 cities (Cityfibre, 2017b). Few months later,

\footnotetext{
${ }^{11}$ Metropolitan area networks (MAN) are backhauling networks interconnecting multiple users and premises across a metropolitan area. 12 The FTTH network in York is being built by a joint-venture between Cityfibre, TalkTalk and Sky.
} 
Vodafone signed an agreement with Cityfibre for the commercialisation of FTTH services to 1 million premises in 12 UK cities (Cityfibre, 2017d). Both announcements followed the decision of the UK government to establish a $£ 400$ m fund to support FTTH deployment across the country (Cityfibre, 2017e).

Local councils often act as anchor customers for Cityfibre's projects, though these have never benefitted from public funds (Oxera, 2013). The provider is not subject to ex-ante regulation and its use of regulated services is limited to passive infrastructure access (Jackson, 2017). Cityfibre has, however, recently lost an appeal against Ofcom's decision to impose a charge control on leased lines. The wholesale fees set by Ofcom were seen as jeopardising the profitability of Cityfibre's investment, thereby hampering infrastructure-based competition (Competition Appeal Tribunal, 2016).

In fact, facility-based competition in the UK has historically been limited to those urban areas served by the cable operator (Ofcom, 2014). The diffusion of local loop unbundling ${ }^{13}$ has fostered competition in the retail market (Lemstra et al., 2014), but ISPs have not invested in their own networks and still rely on the incumbent's infrastructure (Ofcom, 2015). Ofcom (2016) has recently imposed the legal separation of British Telecom to further enhance competition and investment in the NGA market, but this decision has also been criticised by Cityfibre (2017c).

\section{Discussion}

Following the analysis of EU regulation and the longitudinal case studies, this section presents our findings and derives insights into the development of broadband networks by utilities. Our discussion focuses on three issues: the investment strategies of utilities involved in broadband deployment, the effects of policy measures on utilities' projects, and the evolution of utilities as broadband providers in the EU.

\section{I Utility investment strategies in European broadband markets}

The cases presented in Section 6 exemplify the variety of roles that utilities have played in the European telecommunications market since the liberalisation commenced. In each of the

\footnotetext{
${ }^{13}$ Local loop unbundling (LLU) is a wholesale access service that requires ISPs to interconnect at local exchange thereby allowing higher autonomy in the provision of broadband services.
} 
four case study countries, utilities have engaged in the provision of either long-distance or broadband access networks. Nevertheless, their actual contribution to the development of broadband market has been uneven across the four countries - see Table 3 .

In Sweden, many local utilities have consolidated their position and established themselves as major broadband infrastructure providers. In the UK, in contrast, national and local operators have divested from broadband market since the mid-2000s. Consequently, the partners of local utilities, like the predecessor of Cityfibre, have developed alternative models to support fibre deployments.

The cases of Italy and Germany are halfway between these two opposites. Of the many projects launched by Italian utilities in the early 2000s, only Metroweb managed to establish itself as a major competitor of the incumbent, but the former energy monopolist has recently re-entered the broadband market with a nation-wide investment plan. Similarly, the share of local utilities in German broadband market is still limited, although they are the major investors in FTTH networks.

Table 3: Market structure and role of utility providers in the four case study countries

\begin{tabular}{|l|l|l|l|l|l|}
\hline & DE & IT & SE & UK \\
\hline Structure & $\begin{array}{l}\text { Several private } \\
\text { and municipal } \\
\text { providers } \\
\text { (Stadtwerke) }\end{array}$ & $\begin{array}{l}\text { Several private } \\
\text { and municipal } \\
\text { providers }\end{array}$ & $\begin{array}{l}\text { Several private } \\
\text { and municipal } \\
\text { providers }\end{array}$ & $\begin{array}{l}\text { Limited number } \\
\text { of regional } \\
\text { private providers }\end{array}$ \\
\cline { 2 - 6 } & $\begin{array}{l}\text { Involvement in } \\
\text { broadband } \\
\text { market }\end{array}$ & $\begin{array}{l}\text { Many } \\
\text { Stadtwerke are } \\
\text { investing in fibre } \\
\text { networks and } \\
\text { providing } \\
\text { telecom services }\end{array}$ & $\begin{array}{l}\text { Many entered } \\
\text { the market in the } \\
\text { early 2000s, only } \\
\text { few have been } \\
\text { sustainable/are } \\
\text { still operational }\end{array}$ & $\begin{array}{l}\text { Municipal } \\
\text { broadband } \\
\text { networks } \\
\text { provide 58\% of } \\
\text { fibre } \\
\text { connections }\end{array}$ & $\begin{array}{l}\text { Local utilities } \\
\text { partnered with } \\
\text { telcos in the } \\
\text { early 2000s, but } \\
\text { these projects } \\
\text { were later } \\
\text { abandoned/sold }\end{array}$ \\
\hline $\begin{array}{l}\text { Market } \\
\text { structure }\end{array}$ & $\begin{array}{l}\text { Privately owned } \\
\text { companies }\end{array}$ & $\begin{array}{l}\text { Privatised } \\
\text { companies } \\
\text { partially owned } \\
\text { by public entities }\end{array}$ & $\begin{array}{l}\text { Privately and } \\
\text { State-owned } \\
\text { companies }\end{array}$ & $\begin{array}{l}\text { Privately owned } \\
\text { companies }\end{array}$ \\
\cline { 2 - 6 }
\end{tabular}

Source: compiled by the authors. 
Although different roles are evident across the four countries, the case study analysis highlights a number of recurring features in the investment strategies of utilities providing broadband. As summarised in Table 4, their technology, business models and geographic scope generally differ from those adopted by both incumbents and other commercial operators in broadband markets.

Since the late 1990s, utilities have been deploying full-fibre networks regardless of their investment model and their geographical focus. This approach is the opposite to the strategy followed by several European incumbents, such as British Telekom and Deutsche Telekom (Briglauer \& Gugler, 2013), that are primarily investing in FTTC and technologies like G.Fast, to maximise the download speed on the copper subloop (Cullen International, 2016). The choice of FTTB/H also differentiates utilities from traditional ISPs, that have rarely developed their own independent infrastructures (Crandall et al., 2013).

Table 4: The investment strategies of the four case study companies

\begin{tabular}{|c|c|c|c|c|}
\hline & M-net & Metroweb/EOF & Utsikt & Cityfibre \\
\hline Technology & FTTB since 2009 & $\begin{array}{l}\text { FTTH since its } \\
\text { incorporation }\end{array}$ & $\begin{array}{l}\text { FTTH since its } \\
\text { incorporation }\end{array}$ & $\begin{array}{l}\text { Fibre metro } \\
\text { networks }+ \\
\text { FTTH ( } 2 \text { cities })\end{array}$ \\
\hline $\begin{array}{l}\text { Geographic } \\
\text { scope }\end{array}$ & $\begin{array}{l}\text { City of Munich, } \\
\text { Erlangen, } \\
\text { Augsburg and the } \\
\text { neighbouring } \\
\text { rural areas }\end{array}$ & $\begin{array}{l}\text { Initially, only } \\
\text { Milan. Later, } \\
\text { Genova, Bologna } \\
\text { and Torino. } \\
\text { EOF acquired } \\
\text { Metroweb and } \\
\text { plans to cover } \\
224 \text { cities }\end{array}$ & $\begin{array}{l}\text { Mjölby, } \\
\text { Linköping and } \\
\text { Katrineholm } \\
\text { municipalities, } \\
\text { including rural } \\
\text { areas }\end{array}$ & $\begin{array}{l}42 \text { cities across } \\
\text { the UK }\end{array}$ \\
\hline $\begin{array}{l}\text { Investment } \\
\text { model }\end{array}$ & $\begin{array}{l}\text { Municipal } \\
\text { company } \\
\text { regulated by } \\
\text { private law }\end{array}$ & $\begin{array}{l}\text { Initially a } \\
\text { municipal } \\
\text { company, then a } \\
\text { private company } \\
\text { partially owned } \\
\text { by public entities }\end{array}$ & $\begin{array}{l}\text { Municipal } \\
\text { company } \\
\text { regulated by } \\
\text { private law }\end{array}$ & Private company \\
\hline $\begin{array}{l}\text { Business } \\
\text { model }\end{array}$ & $\begin{array}{l}\text { Vertically } \\
\text { integrated }\end{array}$ & $\begin{array}{l}\text { Initially in } \\
\text { partnership with } \\
\text { an ISP. } \\
\text { Wholesale-only } \\
\text { since } 2003\end{array}$ & $\begin{array}{l}\text { Initially vertically } \\
\text { integrated. Now } \\
\text { wholesale-only }\end{array}$ & Wholesale-only \\
\hline $\begin{array}{l}\text { Financial } \\
\text { model }\end{array}$ & $\begin{array}{l}\text { No direct } \\
\text { subsidies }\end{array}$ & $\begin{array}{l}\text { No direct } \\
\text { subsidies except } \\
\text { for deployments } \\
\text { in rural areas }\end{array}$ & $\begin{array}{l}\text { No direct } \\
\text { subsidies except } \\
\text { for deployments } \\
\text { in rural areas }\end{array}$ & $\begin{array}{l}\text { No direct } \\
\text { subsidies }\end{array}$ \\
\hline
\end{tabular}

Source: compiled by the authors. 
Furthermore, most of the utilities involved in the broadband market are wholesale-only operators, whereas the major broadband providers are vertically integrated. It must be noted that, although utilities generally entered the market as vertically-integrated providers or partners of telecommunications operators, they later adopted a wholesale-only business model. This trend is confirmed by the most recent projects we examined: Utsikt, EOF and Cityfibre are operating on an open-access basis and do not directly compete in the retail market.

In terms of geographic scope, all the four case study companies have initially focused on the area they originally served as utility providers, but have later adopted different strategies to extend their coverage. Utsikt and M-Net have gradually expanded their networks into neighbouring areas, so as to also cover suburban and rural communities. On the other hand, Metroweb and Cityfibre have extended their footprint beyond their original area by either deploying new infrastructures or acquiring existing networks in the major cities across Italy and the UK respectively.

Based on the framework described in Section 5, the investment strategies of utilities in broadband markets are expected to be determined by market, policy and technology factors. The next subsection will, as a consequence, focus on the effects of policy dimension to analyse how the regulatory and policy measures described in Section 3 have affected the involvement of utilities and their investment strategies in the four case study countries analysed.

\subsection{The effects of regulatory and policy measures on utilities' broadband projects}

Utilities in broadband markets are subject to both energy and telecommunications regulations, with Germany being the only case study country with a single authority regulating both markets. None of the case study companies has been subject to asymmetric obligations, since these operators are not holding significant power in broadband access markets. Having said that, they could potentially benefit from pro-competitive and pro-investment regulations, like any other operator in the EU electronic communications market.

However, the four case studies indicate that the impact of access regulation on these initiatives has been negligible, as the reliance of utilities on wholesale access to the telecommunications incumbents' networks is generally limited (see Table 5). Even utilities starting out as wholesale customers of the incumbents (like M-net) have later developed their own fully independent networks. Occasionally, they use regulated access to the incumbents' 
ducts and poles, but this approach is considered as supplementary to the development of fully independent infrastructures (Cityfibre, 2017a).

However, utilities have recently opposed some regulatory decisions potentially affecting their investment strategy. For example, Cityfibre contested Ofcom's decision to regulate access to Openreach's dark fibre (Competition Appeal Tribunal, 2016). M-net (2015), instead, criticised BnetzA for allowing the incumbent to deploy vectoring on its copper lines. In both cases, the interventions of national regulatory authorities were seen as a threat to the sustainability of alternative infrastructure investment in future-proof fibre networks.

Table 5: The relevance of policy and regulatory measures for utilities' broadband projects

\begin{tabular}{|c|c|c|c|c|c|}
\hline & Policy & M.net & Metroweb/EOF & Utsikt & Cityfibre \\
\hline & $\begin{array}{l}\text { Public } \\
\text { ownership }\end{array}$ & $\begin{array}{l}\text { The company is } \\
\text { indirectly owned } \\
\text { by multiple } \\
\text { municipalities. }\end{array}$ & $\begin{array}{l}\text { Initially owned } \\
\text { by a municipal } \\
\text { utility, then by } \\
\text { the national } \\
\text { promotional } \\
\text { bank. EOF is } \\
\text { indirectly State- } \\
\text { owned. }\end{array}$ & $\begin{array}{l}\text { The company is } \\
\text { indirectly owned } \\
\text { by multiple } \\
\text { municipalities. }\end{array}$ & $\begin{array}{l}\text { No, the company } \\
\text { is entirely owned } \\
\text { by private } \\
\text { shareholders. }\end{array}$ \\
\hline \multirow{2}{*}{ 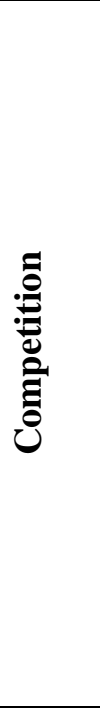 } & $\begin{array}{l}\text { Use of } \\
\text { regulated } \\
\text { wholesale } \\
\text { access services }\end{array}$ & $\begin{array}{l}\text { Initially, relying } \\
\text { on wholesale } \\
\text { access to the } \\
\text { incumbent's } \\
\text { network. Later, } \\
\text { developed a fully } \\
\text { independent } \\
\text { network. }\end{array}$ & $\begin{array}{l}\text { No. Fully } \\
\text { independent } \\
\text { networks since } \\
\text { its inception. }\end{array}$ & $\begin{array}{l}\text { No. Fully } \\
\text { independent } \\
\text { networks since } \\
\text { its inception. }\end{array}$ & $\begin{array}{l}\text { Limited to ducts } \\
\text { and poles. }\end{array}$ \\
\hline & $\begin{array}{l}\text { Non- } \\
\text { discrimination } \\
\text { regulation }\end{array}$ & $\begin{array}{l}\text { No specific } \\
\text { regulation in } \\
\text { favour of open- } \\
\text { access networks. } \\
\text { The incumbent is } \\
\text { vertically } \\
\text { integrated. }\end{array}$ & $\begin{array}{l}\text { The tender for } \\
\text { State aid } \\
\text { favoured open- } \\
\text { access networks. } \\
\text { The incumbent is } \\
\text { vertically } \\
\text { integrated. }\end{array}$ & $\begin{array}{l}\text { Regulation } \\
\text { favours open- } \\
\text { access networks. } \\
\text { The incumbent } \\
\text { implemented } \\
\text { equivalence of } \\
\text { input in } 2015 \text {. }\end{array}$ & $\begin{array}{l}\text { No specific } \\
\text { regulation in } \\
\text { favour of open- } \\
\text { access networks. } \\
\text { Legal separation } \\
\text { of the } \\
\text { incumbent's } \\
\text { network in } 2016 \text {. }\end{array}$ \\
\hline \multirow{2}{*}{ 芯总 } & $\begin{array}{l}\text { Symmetric } \\
\text { regulation }\end{array}$ & No & Yes & No & No \\
\hline & $\begin{array}{l}\text { Reciprocal } \\
\text { access to } \\
\text { existing } \\
\text { networks } \\
\end{array}$ & No & No & No & No \\
\hline
\end{tabular}




\begin{tabular}{|c|c|c|c|c|c|}
\hline 茪 & State aid & $\begin{array}{l}\text { No public funds } \\
\text { awarded. } \\
\text { Collaboration } \\
\text { with the } \\
\text { municipality for } \\
\text { deploying a free } \\
\text { Wi-Fi network. }\end{array}$ & $\begin{array}{l}\text { Metroweb was } \\
\text { not awarded } \\
\text { public funds, } \\
\text { EOF won the } \\
\text { tender for } \\
\text { deploying a } \\
\text { public network } \\
\text { in white areas. }\end{array}$ & $\begin{array}{l}\text { Yes. Public } \\
\text { funds were } \\
\text { awarded to } \\
\text { deploy fibre } \\
\text { connections in } \\
\text { rural areas. }\end{array}$ & $\begin{array}{l}\text { No public funds, } \\
\text { but strong } \\
\text { partnerships with } \\
\text { local councils. }\end{array}$ \\
\hline
\end{tabular}

Source: compiled by the authors

Cityfibre also contested the imposition of structural separation to BT, saying that it could reinforce the monopoly in the infrastructure market and increase the uncertainty for alternative investors (Cityfibre, 2015, 2017c). In fact, non-discrimination regulation can influence the investment strategies of utilities in broadband markets. For example, Utsikt's decision to become a wholesale-only operator was affected by Swedish regulation favouring open-access networks. The emphasis on vertical disintegration in the call for bids gave EOF an advantage in the tender for public subsidies in Italy and was, in turn, contested by the vertically integrated incumbent (CorCom, 2017).

With regard to regulation promoting NGA deployment, there is no clear evidence that these measures have either facilitated or incentivised the collaboration between utilities and telecommunications companies. The Broadband Cost Reduction Directive has been only recently transposed by Member States and further research will be needed to assess the effect of its application. However, it must be noted that none of the case study countries applied the principle of reciprocity envisaged in Directive 2014/61/EU that would have enabled utilities to access telecommunications networks to deploy their own infrastructure.

In fact, the current EU regulatory framework in the electronic communications market was designed to incentivise a shift from service-based to infrastructure-based competition (Cave, 2006). The relevance of ex-ante regulation is, therefore, limited for utilities that leapfrogged the 'ladder of investment' and directly compete with the incumbents in the provision of network access. Nevertheless, ex-ante regulation can indirectly influence the involvement of utilities in broadband development by affecting the size of their market and the sustainability of their business model.

Collaborations with public partners (e.g. local councils or municipalities), state aid and public interventions to reduce digital divide have been more relevant for utilities, with a direct effect on their geographic focus and expansion strategies. Consistent with the EU guidelines, 
broadband deployments in urban areas have not benefitted from public grants or direct subsidies. Nevertheless, the allocation of public funds has enabled Utsikt and EOF to expand their investments to rural areas.

Furthermore, the projects of utilities have benefitted from the non-financial support of public authorities. For example, Metroweb and EOF signed agreements with local authorities to quicken the release of permits for civil engineering works, while M-net is partnering with the Munich municipality for the development of free public Wi-Fi networks (SWM, 2016). Acting as anchor tenants of its networks, local councils have been the strategic partners of Cityfibre. In York, for example, the infrastructure deployed to connect the public sites constituted the foundation for FTTH development to residential users.

In fact, the liberalisation process has not untangled the strong relationship between utilities and public entities (see Table 5). The four case studies reveal that utilities are more likely to invest in the broadband market if they are, at least partially, owned by public entities. Consistently, the contribution of utilities to broadband diffusion has been more significant and systematic in Sweden and Germany, where local utilities are still controlled by municipalities. In contrast, their involvement has been limited in the United Kingdom where utilities are privately owned.

However, direct and indirect ownership are not the only means for local and central governments to influence the involvement of utility providers into the broadband market. Our case studies showed that local authorities can leverage their roles as rule-makers and demand aggregators (Gillett et al., 2004) to foster utility-led deployments, by incorporating broadband in urban planning and public service delivery.

The support of local authorities has been particularly crucial for Cityfibre and Metroweb. Both these companies started up as partnership between telecommunications companies and utility providers. Although this model did not last long, local authorities soon became an alternative partner for the expansion of these initiatives. In fact, neither Cityfibre nor Metroweb (until EOF's acquisition) are no longer related to utility providers. They, instead, cooperate with local councils, acting either as anchor tenants or facilitator of infrastructure rollout.

Neither public ownership nor indirect public support have influenced the financial models of utilities investing in broadband markets. The four case studies are all private-law organisations and their projects have not directly benefitted from public subsidies, in compliance with State aid regulation. However, it is not clear to what extent public utilities 
have been able to leverage cross-subsidies or the credit rating of their shareholders to fund their projects.

On the other hand, the case studies revealed that the involvement of public players is likely to influence the investment strategy in terms of technology. Most of the municipal utilities have invested in fibre networks even when broadband technology was still under development and the demand for gigabit connectivity was unclear. This could be explained by the higher propensity for innovation of publicly owned companies (Carreira \& Deza, 2009; Munari et al., 2010). Furthermore, compared to profit-oriented investors, public shareholders are more likely to accept the longer payback period related to FTTH investments (Wernick et al., 2016).

The nature of the shareholders is also likely to reflect into the geographic coverage of utilities' projects. The case study companies owned by local utilities focused their investment on the respective municipalities and their neighbouring areas. The case of Metroweb shows that a utility's project may expand beyond its local footprint, once it is taken over by a national operator.

The structure and autonomy of local governments has also affected the sustainability of public utilities in broadband market. The pro-activity of Swedish utilities reflects the extensive powers of municipalities to engage in business activities (Argento et al., 2009). In Italy, the decline of municipal broadband projects can be related to the increasing constraints placed on local governments' finance, that limit the ability of municipalities to engage in infrastructure network investments (Barbera et al., 2016).

In summary, the focus on the policy dimension has highlighted how policymakers have affected the development of broadband projects by utilities. Public support and public ownership were found as the most influential drivers, while the relevance of regulatory measures was limited. Nevertheless, the influence of these policy factors has changed over time and differs across the four case study countries. Consequently, the position of utilities in the European broadband markets has also evolved, as shall be discussed in the following subsection.

\subsection{The evolution of utilities' involvement in broadband markets}

Our analysis of investment strategies and policy drivers suggests that the involvement of utilities in the European broadband market has varied over time. After their entry into the telecommunications market (Figure 2), different trajectories can be identified for national and 
local utilities (Figure 3). Each trajectory is composed of three phases, whose duration is not uniform across the case study countries.

As outlined in Figure 2, the decision of national and local utilities to become resellers of telecommunications services in Phase 1 was driven by a mix of technology, market and policy factors. The liberalisation process and the increasing demand for ICT services opened new opportunities for investors in the telecommunications industry. Utilities were in a privileged position to leverage these opportunities, being able to reuse the long-distance and metro networks previously deployed for their internal use.

However, the enthusiasm of national utilities soon cooled, after the advent of DSL technologies and the failure of commercial partnerships with ISPs made evident that the provision of telecommunications services required specific skills and capillary networks (Falch et al., 1999). As a result, in Phase 2 national utilities divested from this market and sold their long-distance infrastructures to telecommunications companies (Figure 3).

Figure 2: Factors driving the entry of utility providers into the telecommunications market

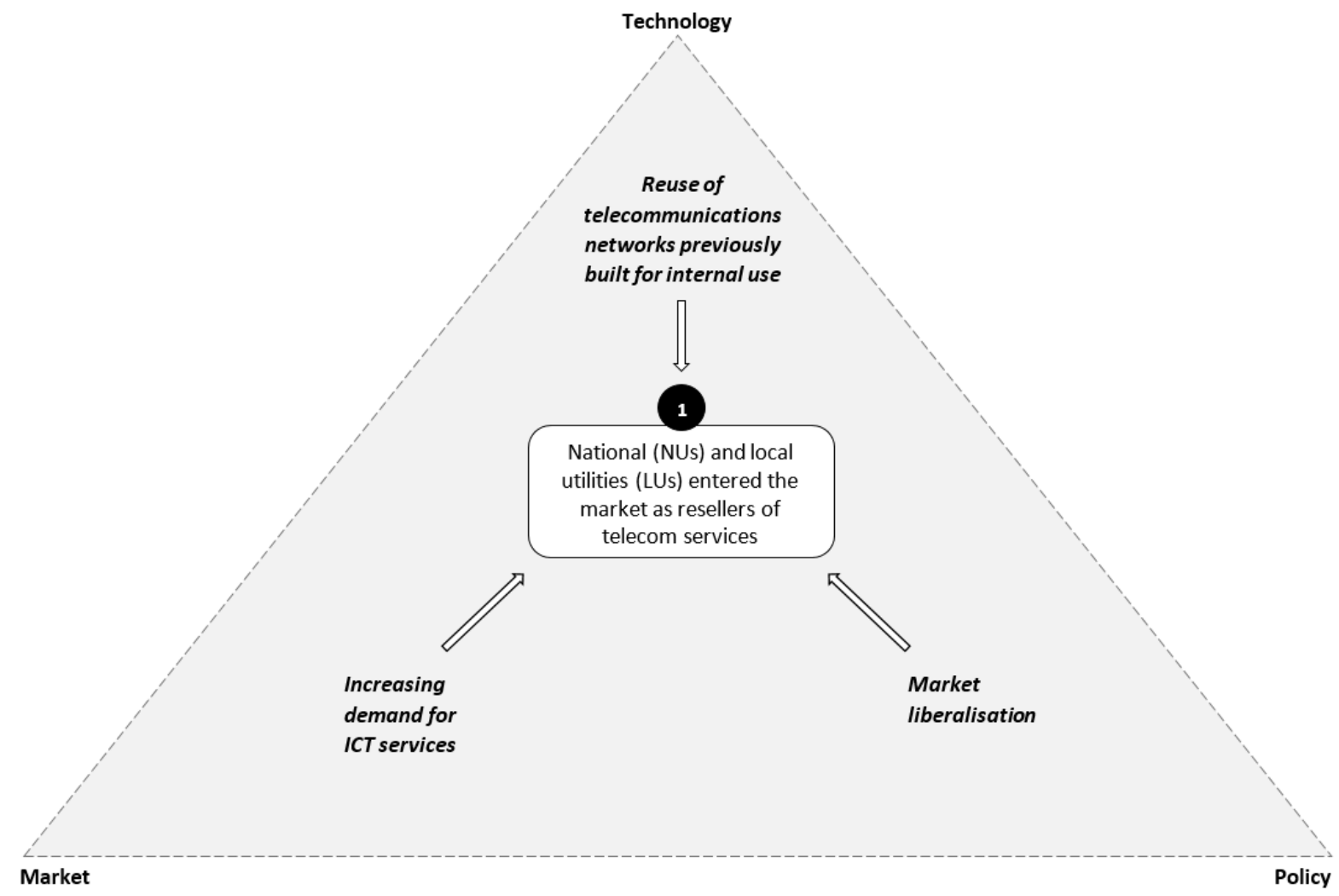

Source: compiled by the authors. 
Figure 3: The evolution of utilities' broadband projects in the case study countries

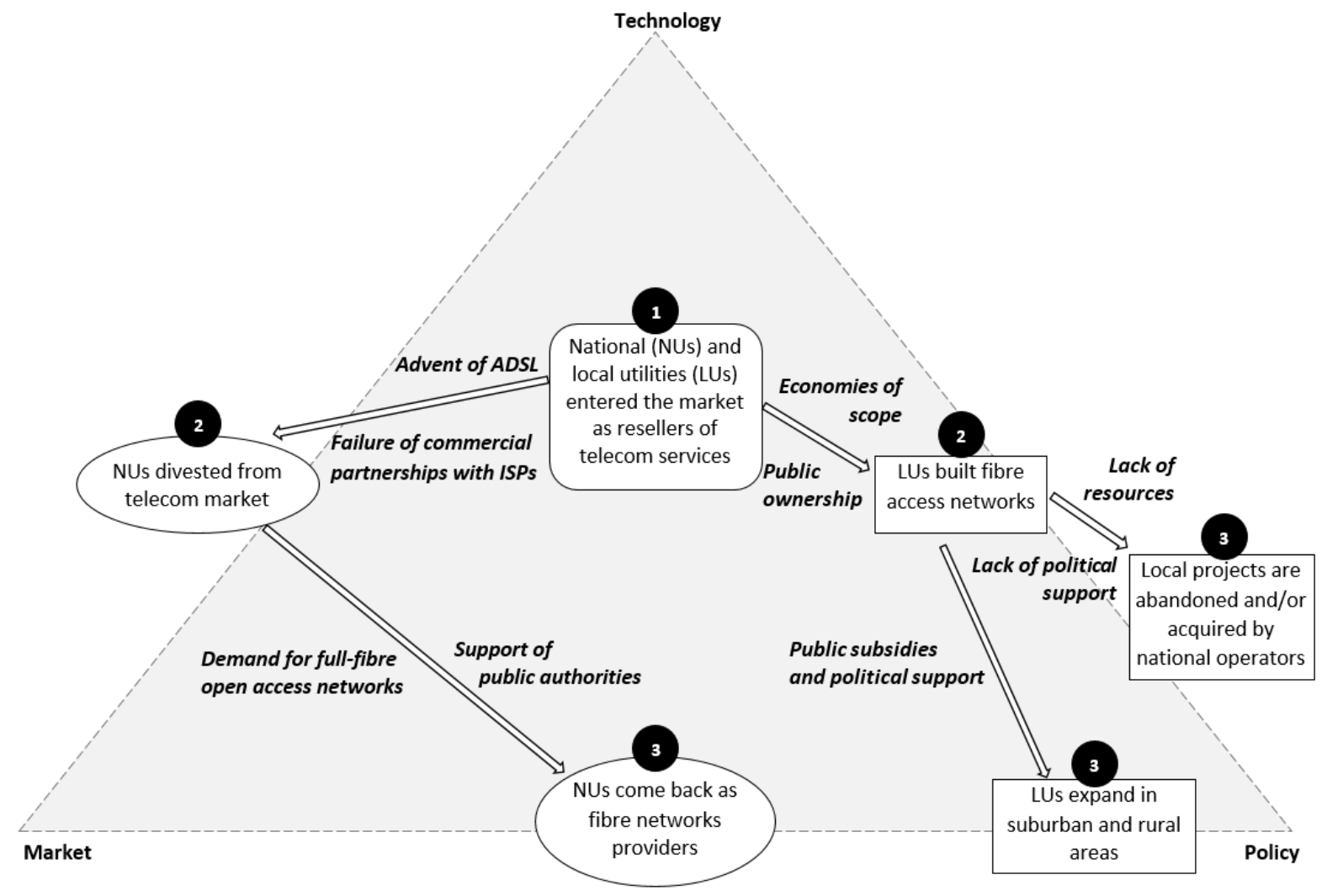

Source: compiled by the authors

Although the resale of telecommunications services was not profitable for local utilities, municipal operators could leverage their existing access networks to develop their own broadband infrastructure. Where local authorities had a higher degree of managerial and financial autonomy, in Phase 2 local utilities deployed independent broadband networks as a means to boost the local economy (Figure 3). After Phase 2, the involvement of local utilities became more dependent on policy factors. In phase 3 , local networks managed to expand when backed by public authorities through direct subsidies or indirect financial aid. On the contrary, other local projects lacking political support were downsized or even abandoned (Figure 3).

However, in phase 3 new initiatives involving national operators have emerged. Encouraged by the escalating demand for full-fibre open-access networks and the increasing support of public authorities for fibre rollout, national utilities have re-entered into the NGA market, by either developing their own infrastructure or integrating existing local networks. Compared to Phase 1, national utilities now more often focus on the wholesale market acting as neutral infrastructure providers. 
The adoption of this wholesale-only model minimises distortions in the retail market and pushes competition in the infrastructure market. In fact, the launch of these initiatives often boosted private and public plans in the NGA market. For example, the UK government announced new funding to support FTTH rollout (DDCMS, 2017), while the Italian incumbent revised its investment plan to include some of the areas covered by EOF with public subsidies (Telecom Italia, 2017).

As outlined in Figure 2 and 3, scope economies were crucial in the Phase 1 and 2, but their relevance has decreased over time. The coordination of civil engineering works is still an opportunity for infrastructure providers, as proven by the recent partnerships between telecommunications companies and national utilities in Germany and Ireland. However, the case of EOF suggests that these synergies may be less decisive than expected. The energy regulator's concerns about cross-subsidisation forced EOF to separate its FTTH rollout from the installation of smart meters, but this has not stopped the company's plans to deploy fibre networks.

Therefore, our analysis shows that the involvement of utilities in NGA development is increasingly driven by a combination of market and policy factors. On the one hand, by developing full-fibre open-access networks, national and local utilities can achieve a firstmover advantage in addressing the increasing demand for faster broadband in those countries where incumbents have focused on FTTC. On the other hand, utilities can leverage their strong relationship with local and national governments that are increasingly supporting the development of ultrafast broadband in compliance with the targets set by the EU.

In fact, the evolution of the role of utilities in broadband markets also highlights how the interest and the involvement of public authorities in this sector has changed over time. In the early 2000s, local utilities were crucial partners for municipalities willing to boost the supply of broadband in their areas. With national governments increasingly taking the lead of public interventions in broadband markets, the scope for local initiatives is less clear and their sustainability largely depends on the powers and resources held by local authorities.

\section{Conclusions}

This paper provided a comprehensive overview of the role of utilities in the EU broadband markets. Since the telecommunications were liberalised, both national and local utility providers have been involved in the provision of both long-distance and access networks. 
Although the similarities in their investment strategies, the contribution of utilities has varied significantly across the EU and over time. The four case studies highlighted two different routes for utilities in broadband market.

Initially, both national and local utilities leveraged the telecommunications networks developed for their internal use to provide voice services in the retail market. Following this phase, the participation of national utilities drastically decreased across the EU. On the other hand, local utilities have progressively established as alternative broadband providers when supported by local authorities. More recently, national utilities have also re-entered the broadband market, focusing on the passive infrastructure layer.

By exploring the factors affecting the investment strategies of utilities in broadband markets, this paper provided helpful insights into the effectiveness of policy and regulatory measures adopted so far in the EU. Our analysis can, therefore, contribute to the ongoing debate over the reform of the Electronic Communications Code and help identifying new measures to enhance the effectiveness of public interventions in NGA markets.

Across these three phases, public support and public ownerships have been the most influential policy drivers over the cases studied, while ex-ante regulation has had a negligible effect on the investment strategies of utilities despite its centrality in the EU broadband policy. The demand for superfast broadband, especially from the public sector, has also become a major driver behind the entry of utilities into NGA markets.

As previously emphasised by scholars and practitioners (Analysis Mason, 2008; Angelou et al., 2013; Tahon et al., 2014), the reuse of passive infrastructure is still an opportunity for utilities investing in broadband networks. Our case study analysis however shows that the relevance of economies of scope has reduced over time. In line with Tadayoni et al. (2007), we observe that either direct or indirect public support has become a determinant of utility-led initiatives in broadband markets.

As a result, the contribution of utilities to broadband development has been more significant in those countries where utilities are, at least partially, owned by public entities. However, direct or indirect ownership is not the only way for local authorities to foster and support these projects. They can push the demand for high-capacity broadband, by incorporating connectivity and digital content in the delivery of public services. Alternatively, they can ease the release of permits to facilitate the rollout of fibre networks. 
Regardless of their ownership, utilities and alternative infrastructure providers in general have become a strategic partner for municipal and regional authorities eager to boost their broadband infrastructure as a source of local competitiveness. Although compliant with State aid, the interventionism of certain public authorities may be at odds with the market-oriented approach advocated by EU regulation.

In fact, these initiatives do not necessarily address a market failure, as utility-led projects often target black and grey areas already provided with superfast broadband by the incumbents. At the same time, they are not aimed to fully replace the current regime that is based on private initiative and competition. Rather, utilities are seen as an alternative to incumbents in the attempt to improve the supply of connectivity, enhance local competitiveness and ensure higher control over local broadband infrastructures.

Consequently, most of the utilities are adopting an open-access model that focuses on the provision of network infrastructure and enables competition at the service level. This approach has been recently endorsed by the European Parliament - see European Parliament (2017), proposing lighter regulation for wholesale-only operators. Its implications for private initiative and innovation in broadband markets are largely unknown.

Further research is, therefore, needed to assess the long-term contribution of utilities to broadband development and clarify the role of national and local authorities in this market, from both an empirical and theoretical perspective. Our case studies highlight that the harmonisation of regulation and broadband policy at EU level has not prevented local authorities from autonomously intervening in support of broadband deployments.

How these local bottom-up initiatives interact with centralised top-down measures, such as ex-ante regulation and state aid, needs further consideration. Extant literature has primarily focused on the interplay between private investment and public interventions, seen as a response to market failures (Gómez-Barroso et al., 2005; Picot et al., 2007), but our case studies suggest that the interaction between local and national institutions should also be taken into account as a variable affecting the development of broadband markets.

Our analysis should, therefore, be extended to other Member States, to enhance the generalisability of our findings and take into account the impact of more recent policies. Furthermore, a comparison between EU and non-EU countries could highlight the impact of different regulatory frameworks on the investment strategies of utilities investing in broadband markets. This would provide useful insights for practitioners and policymakers as well as 
contribute to the theoretical understanding of the role of local and national institutions in the economy.

\section{Acknowledgment}

An earlier version of this paper was presented at the $28^{\text {th }}$ European regional conference of the International Telecommunications Society, $30^{\text {th }}$ July $-2^{\text {th }}$ August, Passau (Germany). We are grateful for the comments that we received and for the constructive and informative comments made by three anonymous reviewers. All errors remain the responsibility of the authors. 


\section{References}

AEEGSI. (2016). Sistemi di smart metering di seconda generazione per la misura di energia elettrica in bassa tensione, conformi ai requisiti funzionali di cui alla deliberazione 87/2016/r/eel. Orientamenti per il riconoscimento dei costi Retrieved from http://www.autorita.energia.it.

AEEGSI. (2017). Relazione annuale. Retrieved from http://www.autorita.energia.it.

AGCOM. (2006). Relazione annuale 2006. Retrieved from https://www.agcom. it/relazioni-annuali.

AGCOM. (2010). Programma AGCOM ISBUL. WP 1.1 - Infrastrutture di rete fissa NGAN. Retrieved from https://www.agcom.it/.

AGCOM. (2013). Delibera n. 538/13/CONS. Regolamentazione simmetrica in materia di accesso alle infrastrutture fisiche di rete. Retrieved from https://www.agcom.it.

Ahl, T. (2017). What is Open Access for us? The Utsikt story of Open Access Networks. Paper presented at the FTTH Conference 2017, Marseille.

Amendola, G. B., \& Pupillo, L. (2008). The Economics of Next Generation Access Networks and Regulatory Governance: Towards Geographic Patterns of Regulation. Communications \& Strategies, 69.

Analysis Mason. (2008). The costs of deploying fibre-based next-generation broadband infrastructure. Final report for the Broadband Stakeholder Group. Retrieved from http://www.broadbanduk.org/wp-content/uploads/2012/08/http wwwbroadbanduk6.pdf

Angelou, G. N., \& Economides, A. A. (2013). Broadband business by utilities infrastructure exploitation: A multistage competition model. Telecommunications Policy, 37(1), 63-79.

Argento, D., Grossi, G., Tagesson, T., \& Collin, S.-O. (2009). The'externalisation'of local public service delivery: experience in Italy and Sweden. International journal of public policy, 5(1), 41-56.

Arrison, S., Rizzuto, R., \& Vasquez, V. (2007). WiFi Waste: The Disaster of Municipal Communications Network. Retrieved from https://www.heartland.org/publicationsresources/publications/wifi-waste-the-disaster-of-municipal-communications-network

Asquer, A. (2011). Liberalization and regulatory reform of network industries: A comparative analysis of Italian public utilities. Utilities Policy, 19(3), 172-184.

Barbera, C., Guarini, E., \& Steccolini, I. (2016). Italian Municipalities and the Fiscal Crisis: Four Strategies for Muddling Through. Financial Accountability \& Management, 32(3), 335-361.

Bauer, J. M. (2010). Regulation, public policy, and investment in communications infrastructure. Telecommunications Policy, 34(1-2), 65-79.

BBC News. (2004). Broadband comes up from the sewer. Retrieved from http://news.bbc.co.uk/1/hi/scotland/3452733.stm

Beckert, B. (2017). Success factors for FTTH deployment in Europe: Learning from the Leaders. Paper presented at the 28th European Regional ITS Conference, Passau. http://hdl.handle.net/10419/169449

BEREC. (2016). Challenges and drivers of NGA rollout and infrastructure competition. Retrieved from http://berec.europa.eu

BnetzA. (2017). Annual report 2016. Retrieved from www. bundesnetzagentur.de

Bognetti, G., \& Robotti, L. (2007). The provision of local public services through mixed enterprises: The italian case. Annals of Public and Cooperative Economics, 78(3), 415-437.

Bös, D. (2015). Pricing and price regulation: an economic theory for public enterprises and public utilities (Vol. 34): Elsevier.

BREKO. (2016). Breko breitband kompass 2016/2017. Retrieved from https://brekoverband.de/download/breitbandkompass-20162017

Brezzi, P. (2004). Economia e politica delle telecomunicazioni. Imprese, strategie e mercati. Milano: FrancoAngeli. 
Briglauer, W., Frubing, S., \& Vogelsang, I. (2014). The Impact of Alternative Public Policies on the Deployment of New Communications Infrastructure-A Survey. Review of Network Economics, 13(3), 227-270.

Briglauer, W., \& Gugler, K. (2013). The deployment and penetration of high-speed fiber networks and services: Why are EU member states lagging behind? Telecommunications Policy, 37(10), 819835.

Briglauer, W., Gugler, K., \& Bohlin, E. (2013). Regulatory approaches and investment in new communications infrastructure. Telecommunications Policy, 37(10), 815-818.

Briglauer, W., Holzleitner, C., \& Vogelsang, I. (2016). The need for more efficient public funding of new communications infrastructure in EU member states. Information Economics and Policy, 36, 26-35.

Broadband Commission. (2015). The state of broadband 2015: broadband as a foundation for sustainable development. Retrieved from Geneva: http://www.broadbandcommission.org/documents/reports/bb-annualreport2015.pdf

Cambini, C., \& Jiang, Y. (2009). Broadband investment and regulation: A literature review. Telecommunications Policy, 33(10), 559-574.

Campesato, G. (2016). Enel Open Fiber, il divorzio per interesse dai contatori intelligenti di Enel. Cor.Com. Retrieved from http://www.corrierecomunicazioni.it/digital/42760 enel-openfiber-il-divorzio-per-interesse-dai-contatori-intelligenti-di-enel.htm

Carreira, M. D. C. S., \& Deza, X. V. $(2009,2009)$. Effects of privatization on innovation: evidence of the Spanish case. Paper presented at the Summer Conference, Copenhagen Business School.

Cave, M. (2006). Encouraging infrastructure competition via the ladder of investment. Telecommunications Policy, 30(3-4), 223-237.

Cave, M., \& Martin, I. (2010). Motives and means for public investment in nationwide next generation networks. Telecommunications Policy, 34(9), 505-512.

CDP. (2012). Banda Larga e Reti di Nuova Generazione.

Chaffee, D., \& Shapiro, M. (2008). The Municipal and Utility Guidebook to Bringing Broadband Fiber Optics to Your Community. Retrieved from http://communitywealth.org/sites/clone.community-wealth.org/files/downloads/tool-broadbandguidebook.pdf

Cityfibre. (2015). 2015 Digital Communications Review. Non-Confidential Version. Response submitted by CityFibre Infrastructure Holdings PLC. Retrieved from https://www.ofcom.org.uk/ data/assets/pdf file/0019/50923/cityfibre.pdf

Cityfibre. (2017a). 2016 Final Results. Meeting UK demand for full fibre connectivity. Retrieved from https://12hdx654n58336ygk21i50nj-wpengine.netdna-ssl.com/wpcontent/uploads/2017/04/CITY-2016-results-presentation-FINAL-1.pdf

Cityfibre. (2017b). 2017 Half Year Results. Focus on densification and commercialisation. Retrieved from https://www.cityfibre.com/wp-content/uploads/2017/09/CITY-2017-Interim-resultsFINAL-1.pdf

Cityfibre. (2017c). Response to legal separation of Openreach [Press release]. Retrieved from https://www.cityfibre.com/news/response-legal-separation-openreach/

Cityfibre. (2017d). Vodafone and CityFibre bring gigabit-speed fibre to the UK [Press release]

Cityfibre. (2017e). The week the UK embraced its full-fibre future. Retrieved from https://www.cityfibre.com/news/week-uk-embraced-full-fibre-future/

Coen, D., \& Doyle, C. (2000). Liberalisation of Utilities and Evolving European Regulation. Economic Outlook, 24(3), 18-26.

Competition Appeal Tribunal. (2016). Notice of appeal under section 192 of the Communications Act 2003. Case no 1261/3/3/16. Retrieved from http://www.catribunal.org.uk/

CorCom. (2017). Banda ultralarga, è scontro aperto Tim-governo. Corriere delle Comunicazioni. Retrieved from http://www.corrierecomunicazioni.it/tlc/47938 banda-ultralarga-e-scontroaperto-tim-governo.htm 
Crandall, R. W., Eisenach, J. A., \& Ingraham, A. T. (2013). The long-run effects of copper-loop unbundling and the implications for fiber. Telecommunications Policy, 37(4-5), 262-281.

Cullen International. (2016). NGA deployment by operators (May 2016). Retrieved from

DDCMS. (2017). The Great British Broadband Boost [Press release]. Retrieved from https://www.gov.uk/government/news/the-great-british-broadband-boost

Delimatsis, P. (2015). The Regulation of Water Services in the EU Internal Market. TILEC Discussion Paper.

Department for Business Innovation and Skills. (2010). Broadband deployment and sharing other utilities' infrastructure. A discussion paper. Retrieved from London: https://www.gov.uk/government/uploads/system/uploads/attachment data/file/72845/101046-broadband-deployment-discussion-paper.pdf

DTAG. (2017). Fiber to the home: Deutsche Telekom pushes build-out [Press release]. Retrieved from https://www.telekom.com/en/media/media-information/archive/fiber-to-the-home-dtpushes-build-out-509334

EC. (2010a). 2010/572/EU: Commission Recommendation of 20 September 2010 on regulated access to Next Generation Access Networks (NGA) Text with EEA relevance. Brussels Retrieved from http://eur-lex.europa.eu/legal-content/EN/TXT/?uri=celex:32010H0572.

EC. (2010b). Communication from the Commission. Europe 2020: a strategy for smart, sustainable and inclusive growth. Retrieved from http://eurlex.europa.eu/LexUriServ/LexUriServ.do?uri=COM:2010:2020:FIN:EN:PDF.

EC. (2013). Communication From the Commission: EU Guidelines for the application of State aid rules in relation to the rapid deployment of broadband networks. (2013/C 25/01).

EC. (2016a). Broadband Coverage in Europe 2015. Mapping progress towards the coverage objectives of the Digital Agenda. Retrieved from https://ec.europa.eu/digital-singlemarket/en/news/broadband-coverage-europe-2015

Proposal for a Directive of the European Parliament and of the Council establishing the European Electronic Communications Code, (2016b).

EC. (2016c). State of the Union 2016: Commission paves the way for more and better internet connectivity for all citizens and businesses [Press release]. Retrieved from http://europa.eu/rapid/press-release IP-16-3008 en.htm

EC. (2017a). Digital Economy and Society Index 2017. Retrieved from https://ec.europa.eu/digitalsingle-market/en/desi

EC. (2017b). Europe's Digital Progress Report. 2017 Country Profile Germany. Retrieved from https://ec.europa.eu/digital-single-market/en/scoreboard/germany

EC. (2017c). Europe's Digital Progress Report. 2017 Country Profile Italy. Retrieved from https://ec.europa.eu/digital-single-market/en/scoreboard/italy

EC. (2017d). Europe's Digital Progress Report. 2017 Country Profile Sweden. Retrieved from https://ec.europa.eu/digital-single-market/en/scoreboard/sweden

Eisenhardt, K. M. (1989). Building Theories From Case Study Research. The Academy of Management Review, 14(4), 532.

EOF. (2016). Presentato al Cda Enel il piano strategico di Open Fiber [Press release]. Retrieved from http://openfiber.it/comunicati/15

EOF. (2017a). Chi siamo. Retrieved from http://openfiber.it/chi-siamo\# obiettivi

EOF. (2017b). I nostri partner. Retrieved from http://openfiber.it/nostri-partner

EOF. (2017c). Infrastrutture telematiche. In 10 Comuni dell'Emilia-Romagna banda ultralarga per il 70\% della popolazione [Press release]. Retrieved from http://openfiber.it/comunicati/19

EOF. (2017d). Open Fiber: Cda approva fusione Metroweb. [Press release]. Retrieved from http://openfiber.it/comunicati/16

EOF. (2018). Roma corre veloce: siglato l'accordo tra Open Fiber e ACEA per la BUL [Press release]. Retrieved from http://openfiber.it/fibra-ottica/news/roma-corre-veloce-siglato-laccordo-traopen-fiber-e-acea-per-la-banda-ultra-larga 
EPEC. (2012). Broadband. Delivering next generation access through PPP. Retrieved from http://www.eib.org/epec/resources/epec broadband en.pdf

On the proposal for a directive of the European Parliament and of the Council establishing the European Electronic Communications Code (EECC) (COM(2016)0590 - C8-0379/2016 2016/0288(COD)), (2017).

EY. (2013). Mapping power and utilities regulation in Europe. Retrieved from http://www.ey.com/Publication/vwLUAssets/Mapping power and utilities regulation in Europe/\$FILE/Mapping power and utilities regulation in Europe DX0181.pdf

F2i. (n.a.). Metroweb. Retrieved from http://www.f2isgr.it/f2isgr/investimenti/portafoglio/metroweb.html

Falch, M., \& Henten, A. (2015). European broadband policy-regulation vs. facilitation. Paper presented at the 26th European Regional ITS Conference, Madrid 2015.

Falch, M., \& Lorz, O. (1999). Electricity Companies and Railway Networks as Newcomers in Telecommunications. In P. J. J. Welfens, G. Yarrow, R. Grinberg, \& C. Graack (Eds.), Towards Competition in Network Industries: Telecommunications, Energy and Transportation in Europe and Russia (pp. 149-169). Berlin, Heidelberg: Springer Berlin Heidelberg.

Feldmann, J., Khodabakhsh, P., Valiucko, D., Weber, C., \& Beck, C. (2014). Study on National Broadband Plans in the EU-28. Retrieved from doi: 10.2759/340045

Ford, G. S. (2007). Does a municipal electric's supply of communications crowd out private communications investment? An empirical study. Energy Economics, 29(3), 467-478.

FTTH Council Europe. (2012). M-net and SWM deploy one of the largest fibre optic networks in Germany. Retrieved from http://www.ftthcouncil.eu/

FTTH Council Europe. (2015). Case studies collection. Retrieved from Brussels: http://www.ftthcouncil.eu/

Gerli, P., Wainwright, D., \& Whalley, J. (2017). Infrastructure investment on the margins of the market: The role of niche infrastructure providers in the UK. Telecommunications Policy.

Gillett, S., Lehr, W. H., \& Osorio, C. (2004). Local government broadband initiatives. Telecommunications Policy, 28(7-8), 537-558.

Gillett, S., Lehr, W. H., \& Osorio, C. A. (2006). Municipal electric utilities' role in telecommunications services. Telecommunications Policy, 30(8-9), 464-480.

Gómez-Barroso, J. L., \& Feijóo, C. (2012). Volition versus feasibility: state aid when aid is looked upon favourably, the broadband example. European journal of law and economics, 34(2), 347-364.

Gómez-Barroso, J. L., \& Pérez-Martínez, J. (2005). Public intervention in the access to advanced telecommunication services: Assessing its theoretical economic basis. Government Information Quarterly, 22(3), 489-504.

Greiling, D. (2013). Stadtwerke Köln: a market-based approach towards public service provision. Retrieved from https://ideas.repec.org/p/crc/wpaper/1304.html

Heddenhausen, M. (2007). Privatisations in Europe's liberalized electricity markets-the cases of the United Kingdom, Sweden, Germany and France. Retrieved from https://www.swpberlin.org/fileadmin/contents/products/projekt papiere/Electricity paper KS IIformatiert.p $\underline{\mathrm{df}}$

Hunt, J. (2010). Fibre through sewers halts in Bournemouth. Retrieved from http://www.thinkbroadband.com/news/4345-fibre-through-sewer-halts-in-

bournemouth.html

Innogy. (2017). innogy and Deutsche Telekom join forces for a faster internet in Germany [Press release]. Retrieved from https://news.innogy.com/innogy-and-deutsche-telekom-join-forcesfor-a-faster-internet-in-germany

Jackson, M. (2017). UPDATE Ofcom Makes BT's UK Cable Ducts and Poles Accessible to FTTP Rivals. ISPreview. Retrieved from http://www.ispreview.co.uk/index.php/2017/04/ofcomproposals-make-bts-uk-cable-ducts-poles-accessible-rivals.html 
Krämer, J., \& Schnurr, D. (2014). A unified framework for open access regulation of telecommunications infrastructure: Review of the economic literature and policy guidelines. Telecommunications Policy, 38(11), 1160-1179.

Lemstra, W., \& Melody, W. (2014). The Dynamics of Broadband Markets in Europe: Realizing the 2020 Digital Agenda (W. Lemstra \& W. H. Melody Eds.). Cambridge: Cambridge University Press.

M-net. (2015). BNetzA-Vectoring-Entwurf: M-net sieht sich in eigener Glasfaser-Strategie bestätigt [Press release]. Retrieved from https://www.m-net.de/ueber-m-net/presse/artikel/news/mnet-sieht-sich-in-eigener-glasfaser-strategie-bestaetigt/

Matson, M., \& Mitchell, R. (2006). Study On Local Open Access Networks For Communities and Municipalities. Retrieved from http://www.infodev.org/en/Document.130.pdf

McNabb, D. E. (2016). Public utilities: essential services, critical infrastructure. Cheltenham, UK: 'Edward Elgar Publishing, Inc.'.

Ménard, C. (2017). Meso-institutions: The variety of regulatory arrangements in the water sector. Utilities Policy.

Mölleryd, B. (2015). Development of High-speed Networks and the Role of Municipal Networks. Retrieved from

Paris: http://www.oecd.org/officialdocuments/publicdisplaydocumentpdf/?cote=DSTI/ICCP/CISP\% 282015\%291/FINAL\&docLanguage=En

Montolio, D., \& Trillas, F. (2013). Regulatory federalism and industrial policy in broadband telecommunications. Information Economics and Policy, 25(1), 18-31.

Munari, F., Oriani, R., \& Sobrero, M. (2010). The effects of owner identity and external governance systems on R\&amp;D investments: A study of Western European firms. Research Policy, 39(8), 1093-1104.

Nucciarelli, A., Sadowski, B., \& Ruhle, E.-O. (2014). Should next generation access networks fall within the scope of universal service? A European union perspective. Government Information Quarterly, 31(1), 90-99.

OECD. (2013). OECD Communications Outlook 2013. Retrieved from www.oecd.org

Ofcom. (2014). Infrastructure Report 2014 (8 December 2014). Retrieved from London: https://www.ofcom.org.uk

Ofcom. (2015). Strategic Review of Digital Communications (16 July 2015). Retrieved from London: www.ofcom.org.uk

Ofcom. (2016). Strengthening Openreach's strategic and operational independence. Retrieved from www.ofcom.org.uk

Ofgem. (2017a). Map: who operates the electricity distribution network? Retrieved from https://www.ofgem.gov.uk/key-term-explained/map-who-operates-electricity-distributionnetwork

Ofgem. (2017b). Map: who operates the gas distribution network? Retrieved from https://www.ofgem.gov.uk/key-term-explained/map-who-operates-gas-distributionnetwork

Ofwat. (2017). Water sector overview. Retrieved from http://www.ofwat.gov.uk/regulatedcompanies/ofwat-industry-overview/

Oxera. (2013). Feasibility and implications of a shared fibre model in UK towns and cities. Retrieved from http://www.oxera.com/Oxera/media/Oxera/downloads/reports/Feasibility-andimplications-of-a-shared-fibre-access-model.pdf?ext=.pdf

Picot, A., \& Wernick, C. (2007). The role of government in broadband access. Telecommunications Policy, 31(10-11), 660-674.

Pinch, S. (1985). Cities and services : the geography of collective consumption. Abingdon-on-Thames: Routledge \& Kegan Paul.

Point Topic. (2017). Country statistics: Germany. Retrieved from point-topic.com/

Pollitt, M. G., \& Steer, S. J. (2012). Economies of scale and scope in network industries: Lessons for the UK water and sewerage sectors. Utilities Policy, 21, 17-31. 
Prinz, R. (2015). Research meets practice. How a large project promotes innovations. Paper presented at the CTTE conference 2015, Munich.

PRISM. (2014). Report on UK NGA provision by non-major providers. A Prism Business consulting report for Ofcom.

Retrieved

from https://www.ofcom.org.uk/ data/assets/pdf file/0020/32519/next-gen.pdf

Ragoobar, T., Whalley, J., \& Harle, D. (2011). Public and private intervention for next-generation access deployment: Possibilities for three European countries. Telecommunications Policy, 35(9-10), 827-841.

RAP. (2015). Report on the German power system. Study commissioned by Agora Energiewende. Retrieved from

https://www.agoraenergiewende.de/fileadmin/downloads/publikationen/CountryProfiles/Agora CP Germany web.pdf

Ray, B. (2008). Thus passes to C\&W. The Register. Retrieved from https://www.theregister.co.uk/2008/09/01/thus cable and wireless/

Sadowski, B., Nucciarelli, A., \& de Rooij, M. (2009). Providing incentives for private investment in municipal broadband networks: Evidence from the Netherlands. Telecommunications Policy, 33(10-11), 582-595.

Seamans, R. C. (2012). Fighting City Hall: Entry Deterrence and Technology Upgrades in Cable TV Markets. Management Science, 58(3), 461-475.

Steitz, C., \& Käckenhoff, T. (2017). Germany's EWE, Deutsche Telekom in talks over broadband push. Reuters. Retrieved from http://uk.reuters.com/article/us-ewe-telecoms-idUKKBN15A11Y

Stephen, G. (1997). Liberalized Utilities, New Technologies and Urban Social Polarization: The UK Experience. European Urban and Regional Studies, 4(2), 135-150.

SWM. (2016). Stadtwerke München. Annual report $2016 . \quad$ Retrieved from https://www.swm.de/dam/swm/dokumente/english/swm-annual-report-2016.pdf

Tadayoni, R., \& Sigurðsson, H. M. (2007). Development of alternative broadband infrastructures - Case studies from Denmark. Telematics and Informatics, 24(4), 331-347.

Tahon, M., Van Ooteghem, J., Casier, K., Verbrugge, S., Colle, D., Pickavet, M., \& Demeester, P. (2014). Improving the FTTH business case-A joint telco-utility network rollout model. Telecommunications Policy, 38(5-6), 426-437.

Telecom Italia. (2017). TIM speeds up UBB coverage in "market failure" areas [Press release]. Retrieved from http://www.telecomitalia.com/tit/en/archivio/media/comunicatistampa/telecom-italia/mercato/business/2017/POSIZIONE-SU-GARA-INFRATEL.html

TeleGeography. (2015). Vodafone Ireland launches 1Gbps broadband service in partnership with ESB. Retrieved

from https://www.telegeography.com/products/commsupdate/articles/2015/11/30/vodafoneireland-launches-1gbps-broadband-service-in-partnership-with-esb/

TeleGeography. (2016a). FNA publishes final Vectoring decision; DT pledges EUR1bn investment. Retrieved from https://www.telegeography.com/products/commsupdate/articles/2016/09/05/fnapublishes-final-vectoring-decision-dt-pledges-eur1bn-investment/

TeleGeography. (2016b). Orange France, SNCF ink wholesale fibre agreement. Retrieved from https://www.telegeography.com/products/commsupdate/articles/2016/05/11/orangefrance-sncf-ink-wholesale-fibre-agreement/

TeleGeography. (2017a). Enel Open Fiber wins first batch of broadband tenders in Italy. Telegeography.

Retrieved from https://www.telegeography.com/products/commsupdate/articles/2017/01/25/enel-openfiber-wins-first-batch-of-broadband-tenders-in-italy/

TeleGeography. (2017b). M-net rolls out G.fast in Munich. Retrieved from https://www.telegeography.com/products/commsupdate/articles/2017/05/09/m-net-rollsout-g-fast-in-munich/ 
Torriti, J. (2010). Impact Assessment and the Liberalization of the EU Energy Markets: Evidence-Based Policy-Making or Policy-Based Evidence-Making? JCMS: Journal of Common Market Studies, 48(4), 1065-1081.

Troulos, C., \& Maglaris, V. (2011). Factors determining municipal broadband strategies across Europe. Telecommunications Policy, 35(9-10), 842-856.

Tsang, E. W. K. (2014). Generalizing from Research Findings: The Merits of Case Studies. International Journal of Management Reviews, 16(4), 369-383.

Van der Wee, M., Beltran, F., \& Verbrugge, S. (2014). Evaluating the impact of financing structure decisions on FTTH deployment. A comparison between New Zealand and Europe. TPRC Conference, Arlington, USA, September.

Van der Wee, M., Casier, K., Dixit, A., Lannoo, B., Verbrugge, S., Colle, D., \& Pickavet, M. (2015). Techno-economic evaluation of open access on FTTH networks. Optical Communications and Networking, IEEE/OSA Journal of, 7(5), 433-444.

Van der Wee, M., Mattsson, C., Raju, A., Braet, O., Nucciarelli, A., Sadowski, B., . . Pickavet, M. (2011). How to measure the success rate of fiber-based access networks? Evaluation of the Stokab case and comparison to other European cases. Journal of the Institute of Telecommunications Professionals, 5(4), 22-31.

Wakefield, J. (2002). Broadband goes down the drain. BBC News,

Walterova, I., \& Tveit, L. (2012). Digital local agenda: bridging the digital divide. Transforming Government: People, Process and Policy, 6(4), 345-357.

Wernick, C., \& Bender, C. M. (2016). The role of municipalities for broadband deployment in rural areas: An economic perspective. Retrieved from www.wik.org

Whalley, J., \& Curwen, P. (2008). Equality of access and local loop unbundling in the UK broadband telecommunications market. Telematics and Informatics, 25(4), 280-291.

WIK. (2011). Study on the Implementation of the existing Broadband Guidelines. COMP/2011/006. Retrieved from www.wik.org

Williams, C. (2008). 100Mbit/s sewer broadband rollout coming your way. The Register. Retrieved from https://www.theregister.co.uk/2008/01/24/h20 sewer rollout/

Wollmann, H. (2013). Public services in european countries between public/municipal and private sector provision - and reverse? Paper presented at the IPSA conference, Grenoble.

Yin, R. K. (2014). Case study research: design and methods (Fifth edition. ed.). Los Angeles, California: SAGE.

Yin, R. K. (2015). Qualitative Research from Start to Finish, Second Edition (2nd ed ed.). New York: New York: Guilford Publications.

Yuill, M. (2004). Endesa's power line broadband coup. A kickstart for utility product expansion? The Register 